Discussion

Papers

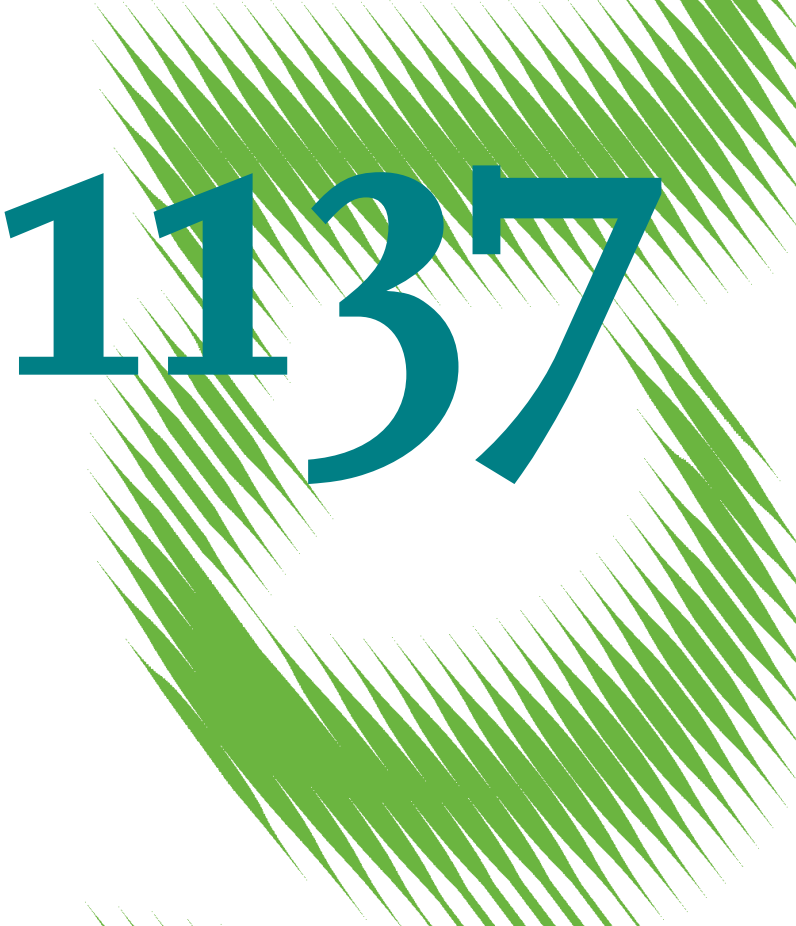

A Wealth Tax on the Rich to Bring down Public Debt?

Revenue and Distributional Effects of a Capital Levy 
Opinions expressed in this paper are those of the author(s) and do not necessarily reflect views of the institute.

IMPRESSUM

(C) DIW Berlin, 2011

DIW Berlin

German Institute for Economic Research

Mohrenstr. 58

10117 Berlin

Tel. $+49(30) 89789-0$

Fax +49 (30) $89789-200$

http://www.diw.de

ISSN print edition $1433-0210$

ISSN electronic edition 1619-4535

Papers can be downloaded free of charge from the DIW Berlin website:

http://www.diw.de/discussionpapers

Discussion Papers of DIW Berlin are indexed in RePEc and SSRN:

http://ideas.repec.org/s/diw/diwwpp.html

http://www.ssrn.com/link/DIW-Berlin-German-Inst-Econ-Res.html 


\title{
A Wealth Tax on the Rich to Bring Ěown Public Debt? Revenue and Distributional Effects of a Capital Levy
}

\author{
Stefan Bach \\ DIW Berlin \\ Martin Beznoska \\ DIW Berlin \\ Viktor Steiner \\ Freie Universität Berlin
}

July 7, 2011

\begin{abstract}
The idea of higher wealth taxes to finance the mounting public debt in the wake of the financial crises is gaining ground in several OECD countries. We evaluate the revenue and distributional effects of a one-time capital levy on personal net wealth that is currently on the German political agenda. We use survey data from the German Socio-Economic Panel (SOEP) and estimate the net wealth distribution at the very top, based on publicly available information about very rich Germans. Since net wealth is strongly concentrated, the capital levy could raise substantial revenue, even if relatively high personal allowances are granted. We also analyze the compliance and administrative costs of the capital levy.
\end{abstract}

Keywords: Capital levy, wealth distribution, microsimulation.

JEL Classification: H24, D31, H22.

Corresponding author: Stefan Bach. DIW Berlin - German Institute for Economic Research. 10108 Berlin, Germany. sbach@diw.de 


\section{Introduction}

The hurricane of the financial crisis is leaving behind public budgets in a state of disorder. Public debt ballooned in several European Union nations as well as in the United States. In some of these countries the ratio of public debt to national income is rapidly becoming hazardous to fiscal sustainability. Even in Germany, which was hit less hard by bank collapses and recovered quickly from the sharp recession, the ratio of public debt to GDP reached 87 percent at the end of 2010, representing an increase of more than 20 percentage points from where it was prior to the crisis. As in most other countries, budget consolidation will be on top of the fiscal policy agenda in Germany over the years to come, calling for spending cuts and tax increases. Since the distribution of income and wealth became more uneven in most advanced economies over the last decades, taxing the "rich" is back on the policy agenda again.

In Germany, a one-time capital levy is proposed in the political debate in order to refinance the sharp increase in public debt caused by the financial crisis. The levy is to be imposed on personal net wealth, i.e., assets minus liabilities. To concentrate the tax burden on the wealthy part of the population, higher personal allowances are proposed. Compared to conventional recurrent taxes on higher income and wealth, the one-time levy is to be imposed on the existing stock of wealth, thereby offering little room for immediate tax avoidance strategies. Still, there are income and wealth effects, and the introduction of a capital levy might change expectations of wealthy people concerning future fiscal policy.

In this study, we evaluate the revenue and distributional effects of a capital levy as proposed, inter alia, by Green Party representatives in the German federal parliament. ${ }^{1}$ This proposal aims at raising tax revenues in the amount of Euro 100 billion from a capital levy, which equals the increase in public debt directly caused by the financial crisis since the end of 2007. We use survey data on households' net wealth stocks from the 2007 wave of the German Socio-Economic Panel (SOEP) and microsimulation modeling to determine the impact of the capital levy on tax revenue and wealth distribution. Since survey data do not represent the high end of wealth distribution well, we include information from a listing of the 300 richest Germans, provided by the business periodical manager magazin. Using Pareto distribution,

1 Our study is based on a research project on behalf of the Green parliamentary group in the German federal parliament (for the detailed final report, see Bach et al., 2010). 
we estimate the wealth distribution of persons with a net wealth of more than Euro 2 million and impute this distribution into our micro data base by adjusting survey weights accordingly. The resulting aggregates on assets and liabilities are consistent with the stocks reported in the national and financial accounts statistics.

Since net wealth is strongly concentrated at the top of the distribution, a capital levy could raise substantial revenue, even if relatively high personal allowances are granted, thus restricting the number affected to a very small percentage of all taxpayers. Assuming a personal allowance of Euro 250,000 we estimate a tax base of Euro 2,950 billion amounting to 118 percent of GDP in 2010. A capital levy raising tax revenue in the amount of Euro 100 billion, or 4 percent of GDP, would thus require a tax rate of 3.4 percent. We also analyze alternative scenarios of a capital levy yielding the same tax revenue with a narrower tax base, and a correspondingly higher tax rate. In the case of a personal allowance of Euro 1 million, which would confine the capital levy to the richest 0.6 percent of the population, the required tax rate would be 5.3 percent. We also analyze the compliance and administrative costs of the capital levy.

We proceed as follows: In section 2, we discuss the capital levy proposal against the background of recent fiscal policy challenges and historical experience. Section 3 describes the data on household wealth including the imputation of wealth at the top of the distribution. The microsimulation model used to assess the impact of the capital levy on tax revenues, implied tax rates and the wealth distribution is described in section 4. Section 5 presents the main results of the study, and section 6 concludes.

\section{A Capital Levy on Personal Net Wealth}

The financial crisis and the subsequent world-wide recession drove public budgets into heavy imbalances. Excessive leveraging in parts of the private sector brought financial markets close to collapse and had to be replaced with public debt and central bank liquidity. Large economic stimulus programs were launched to fight the recession. In most advanced economies, budget deficits exploded and public debt rapidly increased (Figure 1). Compared to 2007, the debt-toGDP ratio for the entire OECD ballooned by 25 percentage points, reaching a level greater than 100 percent in 2011. Debt ratios will increase further since most of the countries continue to run high structural deficits. In particular, the US and UK face large increases in public debt ratios, and they are still running high public deficits. Germany and the overall Euro zone 
will get out of the crisis in relatively good shape, although Greece, Ireland, Portugal and Spain were hit very hard.

Figure 1 General government financial balances and liabilities in selected OECD countries, 2005-2012 as per cent of nominal GDP

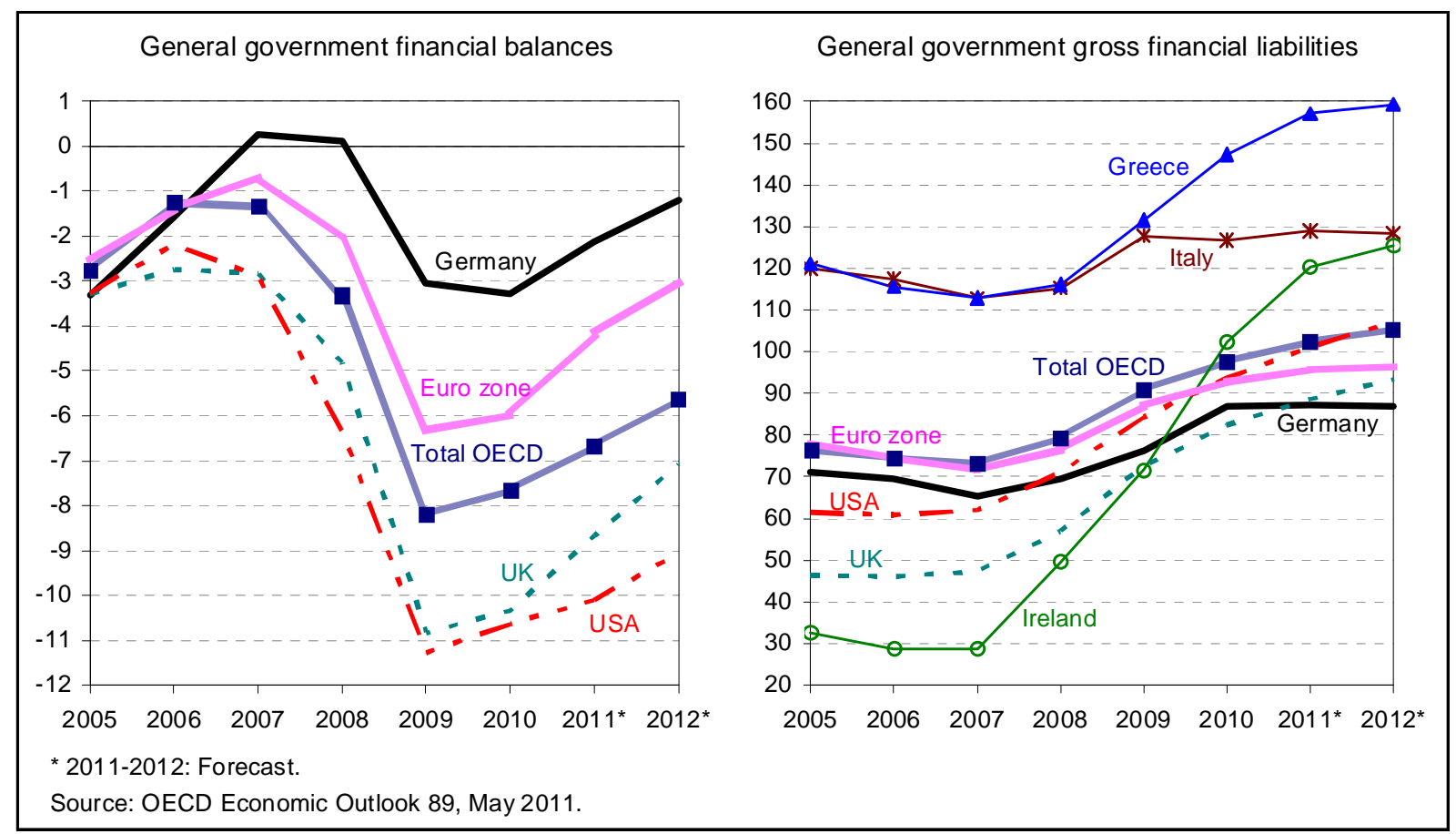

Historical experience and recent studies suggest that a ratio of public debt to national income exceeding 100 percent or more could be hazardous to long-term fiscal sustainability (Kumar and Woo, 2010, Reinhart and Rogoff, 2010). Fiscal retrenchment is critical over the next few years. This requires a well-balanced mix of spending cuts and tax hikes that should seek to harm economic growth as little as possible. Usual topics in these debates are long-term spending cuts of subsidies and social programs, or increments in consumption taxation. However, tax policy increasingly envisages taxing the "rich.” People with higher income and wealth are suggested to bear a greater share of the tax burden. This is more so as the distribution of income and wealth became more uneven in most advanced economies (for the income distribution, see OECD, 2008, Atkinson and Piketty, 2007, 2010).

An alternative to conventional recurrent taxes on higher income and wealth is a one-time capital levy, which is proposed in Germany. The revenue should refinance the increase in public debt immediately caused by the financial crisis. Public funding for bank rescues and economic stimulus programs are estimated to cost at least Euro 100 billion, which equals 4 percent of GDP (IMF, 2010: 7). We assume this amount as the revenue target for the simulations on the capital levy in the following. As Figure 1 shows, the total increase in German 
public debt, since the beginning of the crises, is five times higher, amounting to more than 20 percentage points of GDP.

According to the proposals made during public debate, the levy is to be imposed on personal net wealth, i.e., assets minus liabilities, and should include generous personal allowances in order to focus the tax burden on the wealthy part of the population. We operationalize these features of the proposals by setting the personal allowance to at least Euro 250,000, which would confine the tax burden to the top decile of the net wealth concentration. Furthermore, we analyze scenarios with higher personal allowances (Euro 500,000, Euro 1 million). In addition, parents should benefit from a child allowance for their dependent children. We assume a child allowance of Euro 100,000 or Euro 250,000 in case of the higher personal allowances.

Basically, the tax base of the capital levy is rather similar to a recurrent tax on personal net wealth, which existed in Germany until 1997. For various details regarding tax design, assessment procedures, tax administration, and tax compliance one can refer to the previously existing regulations. With respect to the ascertainment and appraisal of the tax base, which was rather contentious at that time, tax policy might rely on the new valuation procedures introduced for inheritance and gift taxes in 2009. Although there are no clear experiences on the performance of these valuation procedures so far, they aim to capture market values as close as possible for tax purposes. However, standardized appraisal remains an intricate issue (see Rudnick and Gordon, 1996). It is especially challenging to assess standard values for real estate properties and small firms based upon market transactions. In these cases, special valuation procedures, based on standard business and real estate appraisal practices, must be implemented. Moreover, financial assets are often hidden from capital income and wealth taxation in Germany due to bank secrecy regulations. This would, perhaps, require disclosure obligations for financial institutions, in particular, tracer notes for tax purposes, as existent for inheritance and gift taxation in Germany. With respect to the foreign investments of domestic taxpayers, some room for tax evasion will remain since international cooperation between tax authorities is insufficient. This is particularly true for financial investments transferred to offshore banking centers, but it also holds true for real estate and firm shareholdings abroad.

Like the former wealth tax, claims to social security or private pension schemes and similar claims to health and unemployment insurance should be tax-exempt, as long as they do not exceed a certain amount. The same procedure should apply to other household effects such as furniture and motor vehicles. Exemptions might be adopted in the case of higher value household assets, such as expensive cars, yachts, private aircrafts, or collections of art, jewelry, etc. Such assets were taxed by the former German wealth tax when in excess of allowances. Li- 
abilities are to be deducted from the tax base as far as they refer to taxable assets. This does not apply to consumer credits taken out for non taxable household assets.

Unlike the former wealth tax, the capital levy should be confined to individuals. Corporations are exempt since their shareholders are subject to individual taxation. This would avoid double taxation of incorporated firms, but would also exclude foreign shareholders from taxation as well as domestic non-commercial institutions such as governmental bodies, religious communities, associations, unions, etc. Problems might arise with respect to private family foundations or trusts that are often used as holdings for larger family-owned firms. In these cases it may be difficult to identify the beneficiaries to whom the shares are to be assigned (for the UK, see the discussion in Boadway et al., 2010: 785).

In contrast to a recurrent tax on personal net wealth, the one-time levy would be imposed on the existing stock of wealth. For obvious reasons, a valuation date in the recent past must be declared, for example January 1, 2010. As the potentially affected taxpayers did not anticipate the capital levy, taxpayers have no incentives for immediate tax avoidance by adjusting their economic behavior. Insofar, as there are no substitution effects, the levy implies no excess burden in terms of standard optimal taxation theory. However, there are income and wealth effects caused by the tax burden. And, in the long run, the question is how wealthy people would react to the experience of the one time levy with respect to future fiscal policy.

As proposed, the capital levy would be charged at a flat rate, determined by the desired revenue divided by the estimated tax base. A progressive tax scheme might also be possible, by defining brackets of taxable wealth with different tax rates, or by reducing the allowances if the tax base exceeds a certain amount. According to historical examples (see Eichengreen, 1989) and the German capital levy from the fifties (see below), the payment of the levy could be stretched out over a longer period, for instance 10 years, with annuities of tax payments, using a standard interest rate for public debt. This would account for taxpayers' liquidity constraints, especially in the case of business and real estate property. Even in the case of higher tax rates, spreading out payments over a decade would allow the levy to be paid out of current income rather than principal, effectively turn the levy into a recurrent tax on capital income, thus mitigating the income and wealth effects of the tax burden.

Specific reliefs are proposed for business property. These should reduce the tax burden of small and medium sized firms in order to relieve the liquidity constraints of the annual tax payments in the case of a temporary decline in profits. As a separate scenario, we assume a rather generous allowance of Euro 5 million for the net equity of each firm. This would ex- 
empt most small sized firms. Moreover, we restrict the annual tax payment to 35 percent of the annual business income, which would mitigate firms' liquidity problems in economic downturns.

Regarding the practical and political feasibility of a capital levy, Eichengreen (1989) combines theoretical considerations with a historical review of attempts to introduce such a levy in the $20^{\text {th }}$ century. In a standard capital income taxation framework, the welfare improving effect of a capital levy obviously hinges on the perception of the levy's exceptionality. If potential taxpayers expect that the capital levy will be repeated, this could discourage long-term saving and investment, while encouraging capital flight. Eichengreen argues that even if its recurrence cannot be ruled out, a capital levy can be welfare improving if adopted to redress debt problems created by extraordinary circumstances. Historically, this was often the case during or after great wars. In particular, after World War I, several European countries considered capital levies, some implemented them, and, in most cases, the levies failed. Problems of practicability and tax enforcement arose, capital flight occurred since the political deliberations caused delay, and property owners heavily resisted the levy. However, successful capital levies were implemented in post-World War II Japan and Germany.

In particular, the capital levy as the principle financing source in the German "burden sharing” (“Lastenausgleich”) legislation of 1952 was rather successful in raising funds for war indemnities and reconstruction (Wiegand, 1992). A tax rate as high as 50 percent was imposed on personal net wealth exceeding a personal allowance, with payments stretched out over 30 years. The tax burden mainly fell on real estate and business property since financial assets were largely devaluated by the 1948 currency reform. Ultimately the levy raised yearly revenues of about 1 percent of GDP at the beginning of the fifties and was helpful in funding reconstruction and the integration of displaced persons. This experience is present in discussions on capital taxation in Germany today.

\section{Data on Household Wealth and Top Wealth Concentration}

Our analysis is mainly based on the 2007 wave of the German Socioeconomic Panel (SOEP) survey. The SOEP is a representative yearly panel study of private households in Germany (for a detailed description, see Haisken-DeNew and Frick, 2005, Wagner et al., 2007). In 2007 about 20,000 individuals living in approximately 12,000 households were interviewed. For each year, the survey contains detailed information on personal and household income, household composition (marital status, number of children) and personal characteristics of the 
household members. The 2007 wave includes a special wealth survey that provides us with detailed information on the level and composition of wealth of individuals aged over 16 . In particular, the wealth questionnaire records both the gross value of owner-occupied and rented property wealth, outstanding debt on these wealth components, financial and tangible assets as well as related debt, and the estimated value of a business or shares owned in business property. ${ }^{2}$ For real estate and business property the market value as estimated by the respondent is recorded.

An important feature of the SOEP is the special high-income sample that includes about 800 households with monthly household net incomes of at least Euro 3,850 in 2007 (see HaiskenDeNew and Frick, 2005). Since there is a strong positive correlation between income and wealth, and because the capital levy analyzed here is principally targeted on the wealthy population, this oversampling of high-income households in SOEP waves allows us to estimate wealth distribution more precisely. For aggregating the results based on SOEP data, we use the individual-level weights provided by the 2010 SOEP distribution (for the revised weighting scheme, see Kroh, 2009).

A substantial share of respondents only report that they own certain wealth components but do not report the respective amounts. We impute these wealth items following the statistical procedure suggested by Frick et al. $(2007,2010)$. The procedure imputes missing values at the personal level, which cannot directly be inferred from valid household information on the basis of selectivity-corrected regression models for each wealth component. To check to what extent these survey data contain systematic measurement errors, we compare wealth information derived from the SOEP wealth survey for the household sector with aggregate data from the national and financial accounts statistics (for details, see Bach et al., 2010).

Given the modest size of the high-income sample and the fact that the very rich are underrepresented in household surveys, household wealth at the top of the distribution cannot be accurately estimated on the basis of SOEP data alone. The SOEP records 75 persons who report net wealth of at least Euro 2 million, and 20 persons reporting at least Euro 5 million. While the reported net wealth of the richest person in the SOEP was less than Euro 50 million in 2007, it is well known that a substantial number of persons or families living in Germany

2 Recorded financial assets do not include the value of occupational pensions. Tangible assets do not include the value of household furniture and cars owned by the household. Refer to the section "Your personal assets and liabilities” in 2007 questionnaire wave:

http://www.diw.de/documents/dokumentenarchiv/17/diw_01.c.56579.de/personen_en_2007.pdf, pp. 30 ff. 
have wealth exceeding this amount by a large margin. According to the yearly ranking of the 300 richest Germans published by the business periodical manager magazin (2007), the minimum amount of net wealth required to make it on this list was about Euro 350 million in 2007. We estimate the wealth distribution at the very top on the basis of this source and adjust the wealth distribution derived from the SOEP accordingly.

Since we analyze the distribution of wealth at the individual level, we first equally divide the amount of net wealth reported on the mentioned list according to an assumed number of four family members as wealth is reported by family. Persons or families whose ordinary place of residence is known to be abroad are excluded from the sample. We assume that the manager magazin list includes all persons whose net wealth exceeds Euro 300 million in 2007, and that the distribution of net wealth exceeding this threshold can be approximated by the Pareto distribution. ${ }^{3}$ The parameter determining this distribution (Pareto coefficient) is estimated with simple linear regression. For our sample and the mentioned threshold the estimated Pareto coefficient is 1.34 , with an estimated standard error of 0.04 . Using this estimate, we derive the number of persons with a net wealth in the range between Euro 5 to 300 million from the Pareto distribution. Applying this imputation procedure we derive that about 90,000 persons have net wealth of at least Euro 5 million, including all cases from the manager magazin list of the 300 richest Germans. We integrate these cases in our data. In order to adjust the SOEP population weights for the imputed cases of super-rich persons, we reduce the sampling weights of the SOEP cases with net wealth between Euro 2 and 5 million according to the assumed Pareto distribution so that the required adjustment of population weights is achieved. The structure of wealth components for the imputed cases, in particular business property, real estate property and financial assets, are derived on the basis of estimated share equations drawn from the sub-sample of persons with net wealth of at least Euro 1 million before imputation. These estimates imply that the share of business property is increasing in total net wealth. The remaining characteristics that are relevant for the assessment of the capital levy or for the distributional analysis, for instance the age or the number of children, are imputed using mean values from the SOEP cases representing the top 40,000 persons of the net wealth distribution before imputation.

3 For the use of the Pareto distribution in the analysis of the distribution of very high wealth see, e.g., Klass et al. (2006). 
The imputation at the top of the distribution results in a substantial increase in the estimated amount of personal net wealth by almost Euro 1,200 billion. The resulting total amount of personal net wealth of Euro 7,225 billion, derived on the basis of this imputation and the SOEP data, is very close to the corresponding amount of Euro 7,240 billion found by the macroeconomic aggregates reported in national and financial accounts statistics (see Table A-1 in the Appendix). ${ }^{4}$ This substantial increase in the amount of personal net wealth is mainly due to the relatively large amount of business property owned by the imputed cases at the top of the distribution, whereas the other wealth components are slightly reduced as a result of the imputation and the corresponding reduction of the sampling weights of the observations with a net wealth below Euro 5 million, respectively (for details, see Bach et al., 2010).

The left part of Table 1 shows the distribution of personal net wealth including imputations for non-response based on the SOEP data alone, while the right part also includes the imputed amounts of personal net wealth at the top of the distribution. Personal net wealth is highly concentrated even without imputing wealth at the very top of the distribution, as indicated by a value of the Gini-coefficient of 0.7726 reported at the bottom of the table. The breakdown of the wealth distribution by percentiles shows that only 2 percent of total net wealth is owned by the bottom-half of the distribution, whereas more than 60 percent of it is held by the top decile of the distribution. More than 23 percent by the top 1 percent and almost 9 percent of total net wealth is owned by the top 0.1 percent. The increase in the wealth concentration is substantial when imputed wealth at the very top of the distribution is added. The Gini coefficient jumps to 0.8097, the more top-sensitive entropy measures, in particular the GE(2) measure (which equals half the squared coefficient of variation), indicate a much stronger increase in wealth inequality. The share of personal net wealth owned by the top 1 percent of the distribution increases to more than a third, and the share of the top 0.1 percent nearly triples. This underlines the importance of imputing wealth at the very top of the distribution, which is usually not represented in survey data, and at the same time also indicates that estimates of total wealth may be sensitive to the imputation procedure.

4 From the total amount of net wealth reported in the national accounts we have deducted the following items that are not recorded in the SOEP data base (see Table A-1 in the Appendix): consumer durables, the value of occupational pensions and private health insurance schemes, currency and transferable bank deposits, and consumer loans. 
Table 1 Distribution of personal net wealth in Germany, 2007

\begin{tabular}{|c|c|c|c|c|c|c|}
\hline \multirow{3}{*}{$\begin{array}{l}\text { Fractiles }^{1)} \\
\text { personal net } \\
\text { wealth }\end{array}$} & \multicolumn{3}{|c|}{ Database SOEP } & \multicolumn{3}{|c|}{$\begin{array}{c}\text { Database SOEP including imputed } \\
\text { top wealth distribution }\end{array}$} \\
\hline & \multirow{2}{*}{\begin{tabular}{|l|} 
Percentile \\
1000 Euro
\end{tabular}} & \multicolumn{2}{|c|}{ Total } & \multirow{2}{*}{$\frac{\text { Percentile }}{1000 \text { Euro }}$} & \multicolumn{2}{|c|}{ Total } \\
\hline & & bill. Euro & $\%$ & & bill. Euro & $\%$ \\
\hline $1^{\text {st }}-5^{\text {th }}$ decile & 1 & 103 & 1.7 & 1 & 103 & 1.4 \\
\hline $6^{\text {th }}-9^{\text {th }}$ decile & 16 & 2310 & 38.2 & 16 & 2310 & 32.0 \\
\hline $10^{\text {th }}$ decile & 210 & 3633 & 60.1 & 210 & 4813 & 66.6 \\
\hline Total & 1 & 6045 & 100.0 & 1 & 7225 & 100.0 \\
\hline Top 7,5\% & 256 & 3227 & 53.4 & 256 & 4408 & 61.0 \\
\hline Top 2,5\% & 492 & 2046 & 33.9 & 492 & 3227 & 44.7 \\
\hline Top 1\% & 772 & 1409 & 23.3 & 772 & 2590 & 35.8 \\
\hline Top 0,5\% & 1200 & 1072 & 17.7 & 1200 & 2252 & 31.2 \\
\hline \multirow[t]{2}{*}{ Top 0,1\% } & 4079 & 520 & 8.6 & 6080 & 1627 & 22.5 \\
\hline & \multicolumn{6}{|c|}{ For information: Summary inequality measures of personal net wealth } \\
\hline Gini coefficient & & 0.7726 & & & 0.8097 & \\
\hline Entropy meas. & & & & & & \\
\hline GE(1) & & 1.3801 & & & 2.2201 & \\
\hline $\mathrm{GE}(2)$ & & 7.0211 & & & 697.6914 & \\
\hline
\end{tabular}

Our data reflects the 2007 wealth distribution, the year of the most recent wealth survey collected in the SOEP. We abstain from uprating the data base to the present. Basically, household wealth in Germany should not have changed significantly in the meantime. Although the financial crisis has devaluated several assets, businesses and stock markets strongly recovered during 2009 and 2010. Real estate markets performed rather moderately in Germany over the last decade and were not strongly affected by the crisis. Taking into account additional savings, household wealth stock in 2011 should be slightly higher than in 2007.

\section{Microsimulation Modeling of Personal Wealth Taxation}

Using the edited and adjusted micro data base described in the previous section, we built a microsimulation model of personal wealth taxation. Modeling the tax base, we start from the compilation of the various assets and liabilities, take into account the specific reliefs for business property, and include personal and child allowances, for which we assume different scenarios. We also analyze the compliance and administrative costs of the capital levy.

We analyze three scenarios of personal and child allowances, which represent different degrees of a broader or narrower tax base. In order to confine the tax base to the top decile of the wealth distribution, we set the personal allowance to at least Euro 250,000, and the child allowance to Euro 100,000. Scenarios with higher personal allowances, respectively, Euro 
500,000 and Euro 1 million, both combined with a child allowance of Euro 250,000, focus the tax burden at the very top of the wealth distribution.

We align these scenarios to a further scenario taking into account specific reliefs for business property. This scenario includes an extra allowance of Euro 5 million on the net equity of each firm. Notably, the allowance is granted only once per firm. Therefore, we impute information on the distribution of firm size and number of shareholders from tax statistics, in order to estimate the firm size of the shareholdings observed. Moreover, we restrict the annual tax payments to 35 percent of the annual business income, less imputed entrepreneurial profit. For that purpose, we edit the survey information on business income and estimate a fictitious wage for the self-employed, using standard wage regression models accounting for selection effects (for details, see Bach et al., 2010: 55).

The child allowances can be derived using the detailed information on household composition. The entitlement to the allowance, which includes dependent adult children in education or severely disabled children, follows the corresponding regulations in personal income taxation.

The tax rate of the capital levy is calculated by dividing the revenue target of Euro 100 billion by the estimated tax base of the respective scenarios assuming a flat rate. The payment of the levy is stretched out over 10 years. The yearly annuities are calculated using an interest rate of 4.0 percent, which is derived from the longer-term average of government bonds of that maturity.

The compliance and administrative costs of wealth taxation have been rather contentious in policy debates (see Boadway et al., 2010, Rudnick and Gordon, 1996). In particular, the inexactness of real estate appraisal is considered as a main obstacle in a fundamental reassessment of the outdated standard values for wealth taxation in Germany. Using the detailed information of the micro data base we simulate the potential compliance and administrative costs, taking into account the incentives of taxpayers to appeal against assessments (for details, see Bach et al., 2010: 67). For the valuation of assets and assessment procedures, we rely on standard cost rates from the fiscal authorities and estimations on the time involved for compliance. With respect to the potential estimation errors of the real estate appraisal, which are deemed to be rather high, we use empirical information on the performance of the new valuation schemes used for inheritance and gift taxation. Studies show that the valuation procedures appear to be unbiased, but have a larger standard error. By imputing normally distributed error terms on the observed values in the data set, we simulate the potential estimation 
error of the real estate appraisal. Based on this distribution, we analyze the potential for remonstrance against the values assessed by the fiscal authorities by simply modeling the incentives of the taxpayers. Beside extra costs for the appeal procedures and certified appraisals, our results suggest the valuation corrections might result in a significant tax revenue shortfall. The owners of the noticeable overvalued properties would appeal in order to adjust the valuation, whereas, no such correction would happen in the opposite direction in case of the undervalued properties.

Regarding the reliability of our estimations of the revenue and distributional effects presented in the following section 5, some caveats are in order. Our simulations mainly rely on the German SOEP, which is a relatively small stratified random sample of the non-institutionalized population living in Germany. The 2007 wave of the SOEP includes 20,000 persons aged over 16 in 12,000 households. The average sampling probability is 0.03 percent, within the high-income sample it amounts to 0.083 percent. Given the rather small number of observations and the huge variance in the very top wealth percentiles on which the capital levy is concentrated, the standard error of estimations on tax base, revenue, and distribution of the levy is likely to be fairly large. Actually, the confidence intervals we report for the main results in the following section 5 are rather high. These are based on estimated robust standard errors and include the estimation errors of the imputed top wealth concentration. Given the high importance of imputed wealth at the top of the distribution for the tax base (see the following section 5), further estimation risks emerge with respect to the validity of the Pareto distribution and its estimation based on the listing of the top wealthiest persons. Although the validity of the Pareto distribution for the very top income and wealth distribution is often approved, we cannot test it for the interval between the wealthiest persons observed in the SOEP and the listing of the 300 wealthiest Germans.

Further measurement errors are hard to assess given the information available. We cannot evaluate the self-assessed property valuations of the SOEP respondents since there is no additional information on the characteristics on the respective assets. In any case, we have no evidence on a systematic bias in this respect. The point estimate on net wealth aggregates captures the aggregates from macroeconomic wealth accounts for households. However, these macroeconomic figures could be plagued by several estimation risks as well. Comprehensive information on real estate and business property derived from market transactions or financial accounting do not exist in Germany. Even the Bundesbank's macroeconomic financial accounts, which are based on the banking and capital market statistics, could fall short in fully reporting the households' financial investments abroad. Moreover, it remains unclear if fiscal 
authorities would actually succeed in fully ascertaining and valuing all taxable properties. Thus, a significant measurement error would clearly remain. This means that our results presented in the following section should be treated with some caution.

\section{Tax Base, Tax Rate, and Distributional Effects of a Capital Levy}

The "first-round" effects of the capital levy on the tax base and the wealth distribution presented in the following do not include behavioral responses of the taxpayers to the extra tax burden. However, as discussed above (see section 2), a one-time levy imposed on the existing stock of wealth does not provide incentives for immediate adjustments in economic behavior. Insofar as there will be no substitution effects of the levy, only income and wealth effects, for instance on saving and investment. Moreover, liquidity constraints might cause financial troubles in the case of business and real estate property, although mitigated through tax reliefs and the 10 year payment period. These effects are neglected in the following. We only model the potential of appeal of the taxpayers against the real estate values assessed by the fiscal authorities, and the revenue losses incurred.

Since net wealth is heavily concentrated at the top percentiles of the population, wealth taxation could raise substantial revenue even if relatively generous personal allowances are granted (Table 2). In the case of a personal allowance of Euro 250,000 and a child allowance of Euro 250,000 we estimate a tax base of Euro 2,952 billion, neglecting the allowance for business property. This tax base amounts to 118 percent of GDP in 2010. Thus, an annual wealth tax at a rate of 0.5 could raise tax revenue of Euro 15 billion, or 0.6 percent of GDP. About 4.8 million persons, or 7 percent of the population aged over 16, would be liable to the tax.

In the case of a rather generous personal allowance of Euro 1 million, the tax base is still estimated at Euro 1,875 billion, or 75 percent of GDP. Thus, an annual wealth tax at a rate of 0.5 could raise tax revenue of almost Euro 9.4 billion, or 0.4 percent of GDP. The number of affected taxpayers declines to 414,000 persons ( 0.6 percent of the population over 16 ). The specific allowance for business property clearly reduces the tax base by 21 percent for the lower personal allowances, and by about 25 percent for the higher allowances.

Due to the estimation uncertainty resulting from the sampling error of SOEP data and the imputation of the top wealth distribution, the estimated 95 percent confidence intervals for the tax base are rather wide. For the lower personal allowances they amount to about +/- 30 percent of the point estimate. They increase to +/- 40 percent for the high allowances. 
Table 2 Tax base of the capital levy for alternative scenarios

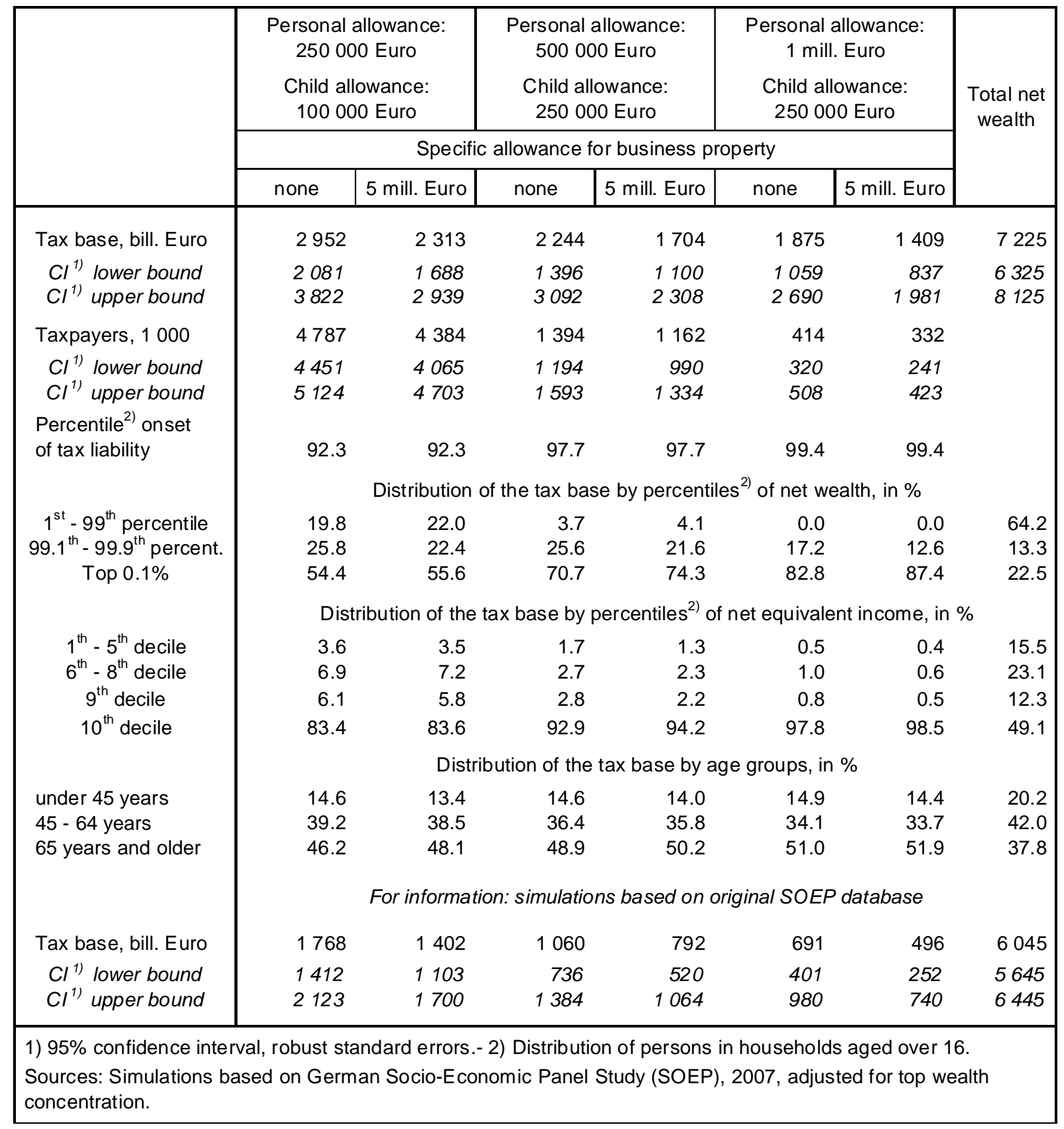

The results, shown by net wealth percentiles, underline the high wealth concentration at the top percentiles. In the case of the lower allowances, the top 0.1 percent wealthiest persons account for 55 percent of the tax base, compared to 23 percent of total net wealth. This share significantly increases with higher personal allowances. In the scenario with a personal allowance of Euro 1 million and a child allowance of Euro 250,000, the tax burden is completely concentrated on the top 1 percent of the wealth distribution. In this case, the top 0.1 percent wealthiest persons account for 83 percent of the tax base, or 87 percent for the scenario including the allowance for business property. 
We further report the distribution of the tax base by net equivalent income, which is calculated based on net household income including imputed rent and weighted by the modified OECD equivalence scale. The concentration at the top income decile is also pronounced, but less than for wealth concentration. This comes from wage and transfer income, whose underlying implicit wealth stocks, "human capital” and "social capital”, are not or only partly included in the tax base.

The tax base is more heavily concentrated on older people when compared to the overall distribution of net wealth. Since these persons often no longer have children eligible for the child benefit, the impact of the child allowance is not so strong. A separate simulation (which is not provided here) shows that the tax base would increase only by 1.7 percent if we reduce the child benefit from Euro 250,000 to Euro 100,000 for the middle scenario of the personal allowance (Euro 500,000).

At the bottom panel of Table 2 we include information on the tax base that would result from calculations without imputation of the top wealth distribution. As described above, this imputation has a strong effect on wealth aggregates and concentration. While the imputation increases total net wealth by 20 percent, the tax base increases by 67 percent in the scenario with the lowest allowances. With the highest allowance, including that for business taxation, the tax base nearly triples. This emphasizes the importance of accounting for top wealth concentration in modeling the revenue and distributional effects of wealth taxation with higher allowances. However, this also sheds light to the relevance of estimation risks involved with our estimation procedure.

The tax rate of the capital levy is calculated by dividing the targeted revenue of Euro 100 billion by the estimated tax base of the respective scenarios (Table 3). For the scenarios including special allowances for business property, we further restrict the annual tax payments to 35 percent of the annual business income. Therefore, we iteratively increase the tax rate until we achieve the fixed revenue target. In Table 5 we display both the entire tax rate, which is required to raise the revenue target of Euro 100 billion, and the annual tax rate calculated as annuity over 10 years with an interest rate of 4.0 percent. Due to compounded interest, the annual tax rate is 21 percent higher than one tenth of the tax rate for the whole 10-years' period. 
Table 3 Tax rate and distributional effects of the capital levy for alternative scenarios and a targeted tax revenue of Euro 100 billion

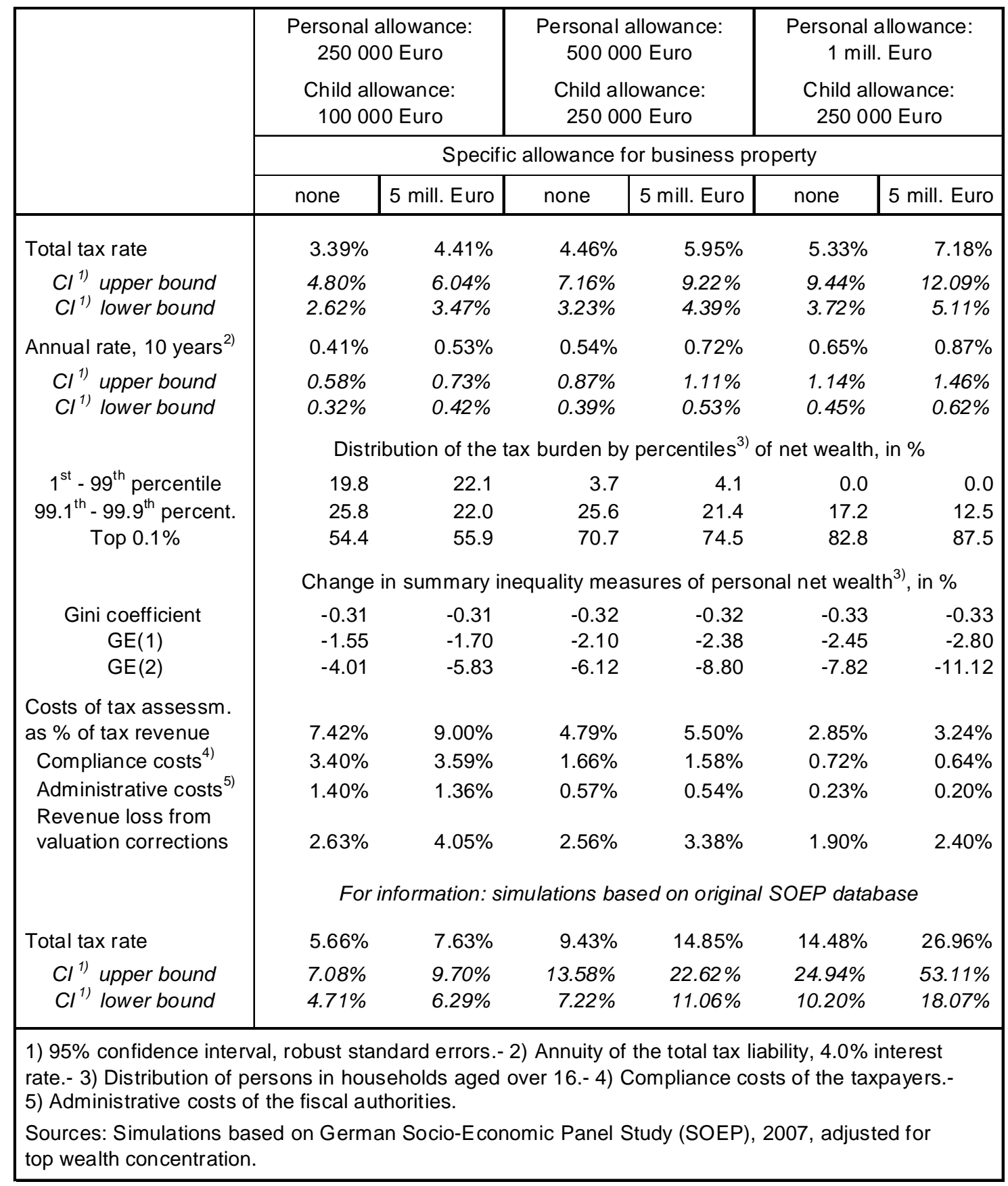

The narrower the tax base is determined, the higher the tax rate must be fixed in order to realize the revenue target of Euro 100 billion. However, even in the case of the rather generous personal allowance of Euro 1 million, which would confine the capital levy to the richest 0.6 percent of the population, the annual tax rates still might be deemed as rather modest, as it amounts to 0.65 percent, or 0.87 percent in the case of the special reliefs for business property. This result again underlines the high wealth concentration. Yet, the estimation risks are rather high, in particular for the scenarios with the high allowances. Looking at the upper bound of the confidence interval the respective annual tax rate ranges at 1.14, or 1.46 percent. 
Notably, the confidence intervals estimated for the tax rates are not symmetrically distributed around the point estimate since the tax rate is determined for the fixed revenue target Euro 100 billion, which is divided by the respective tax base.

The distribution of the tax burden by net wealth closely corresponds to the distribution of the tax base presented in Table 2. In the case with specific reliefs for business property the tax burden is concentrated somewhat more heavily at the top percentiles. This results from restricting the annual tax payments to 35 percent of the annual business income. Moreover, we report the effect of the capital levy on the summary inequality measures, for which we display the relative change. We account for the entire capital levy burden in relation to the existing net wealth. The Gini coefficient, which is known to be sensitive to changes at the middle of the distribution, increases only a little due to higher allowances. The top-sensitive GE(2) measure indicates a much stronger reduction in wealth inequality, which markedly increases with higher allowances. Also the specific reliefs for business property reduce the wealth income inequality more than the respective scenarios without such reliefs. Obviously, the persons with lower business property and net wealth benefit relatively more from this relief.

The costs of tax assessment strongly depend on the number of taxpayers. This is especially true for the compliance costs of taxpayers and the administrative costs of tax authorities. Raising the fixed revenue target from a significantly smaller number of taxpayers would reduce the assessment effort. The total cost share for compliance and administration makes up around 5 percent of tax revenue for the scenarios with the low personal allowance, and decrease to below 1 percent for the scenarios with the high personal allowance. The picture is less clear regarding the estimated revenue loss resulting from valuation corrections for real estate property. On the one hand, the share of real estate in total wealth declines with higher personal allowances, which would reduce the impact of the valuation corrections. On the other hand, higher allowances require higher tax rates in order to raise the targeted revenue amount, thus increasing the taxpayers' incentives of to appeal against assessments, which we model in our simulations. On balance, the total costs slightly decline with higher personal allowances.

At the bottom of Table 3, we also report the tax rates that result from a simulation that uses only SOEP data, without imputed top wealth concentration. Correspondingly, the tax rates would be much higher, in particular for the case of the high allowances. 


\section{Summary and Conclusion}

The idea of higher wealth taxes to finance the mounting public debt in the wake of the financial crises is gaining ground in several OECD countries. In this study, we evaluate the revenue and distributional effects of a capital levy as proposed in the current German political debate. The levy aims at raising tax revenue of Euro 100 billion. Higher personal allowances would concentrate the tax burden on the wealthy part of the population.

Our empirical analysis is based on household survey data from the 2007 wave of the German Socio-Economic Panel (SOEP) and microsimulation modeling. Since survey data do not represent the high end of wealth distribution well, we include information from a listing of the 300 richest Germans, provided by manager magazin. Using the Pareto distribution, we estimate the wealth distribution of persons owning net wealth of more than Euro 2 million and impute this distribution into the micro data base. The resulting aggregates on personal wealth are consistent with the stocks reported in the national and financial accounts statistics. Based on this data set, we built up a microsimulation model on wealth taxation.

Our simulations show that wealth taxation could raise a substantial amount of revenue, even if higher personal allowances target the tax to those in the top percentiles of the wealth distribution, Yet, even if high personal allowances are set, the annual tax rates required to yield revenues in the amount of Euro 100 billion, i.e., 4 percent of GDP, seem rather modest. For a personal allowance of Euro 1 million, which would confine the capital levy to the richest 0.6 percent of the population, we estimate the annual tax rate to 0.65 percent, or 0.87 percent if special reliefs for business property are included. Moreover, raising the tax revenue from the top percentiles of the wealth distribution would reduce the costs of assessment.

It should be noted that our empirical analysis includes several estimation risks. The standard error resulting from the sampling error of the survey data is rather large, in particular with respect to the high personal allowances. Further estimation risks emerge from the imputation strategy of the top wealth concentration that relies on the Pareto distribution, and from measurement errors regarding the information on household wealth. In particular, it seems unclear if fiscal authorities can actually succeed in fully ascertaining and valuing taxable properties. Therefore, to be on the safe side of estimates for the tax base of the capital levy, we would recommend focusing on the lower bound of the confidence intervals reported. Correspondingly, the tax rates required for the revenue target should be oriented towards the upper bound of the confidence intervals. For the scenario with a personal allowance of Euro 1 million this 
would imply an annual tax rate of 1.14 percent, or 1.46 percent in the case of the special reliefs for business property.

We have not analyzed further economic effects of the capital levy. As taxpayers could not anticipate it, no immediate substitution effects are involved in the short run. However, there will be long-term income and wealth effects. Savings or bequests and gifts might be adjusted to compensate the extra tax burden. In the case of real estate and business property, frustration with deficient valuation procedures could enhance political resistance against the levy. Liquidity constraints might cause problems, which could be addressed by tax reliefs or longer payment periods. In the long run, the impact on the behavior of the wealthy elite significantly depends upon if the levy is perceived as exceptional or not. Saving and investment might be discouraged if potential taxpayers expect that the capital levy will be repeated. Finally, as historical experience suggests, the feasibility of a capital levy would considerably depend on the attitude and perception of the wealthy elite with respect to the political exigency to resort to such an extraordinary fiscal policy measure.

A fiscal instrument rather similar to a capital levy is a compulsory loan. Historically, governments with bad credit often resorted to using this instrument. It might be tempting to governments to combine both instruments in times of debt overhang, thus promising that the levy will be converted into loans once fiscal sustainability is regained. 


\section{Appendix}

Table A-1 Assets and liabilities of households in Germany according to national and financial accounts statistics, 2007

End-of-year level

\begin{tabular}{|c|c|c|c|c|c|}
\hline Assets & $\begin{array}{c}\text { billion } \\
\text { Euro }\end{array}$ & $\%$ & Liabilities & $\begin{array}{c}\text { billion } \\
\text { Euro }\end{array}$ & $\%$ \\
\hline Fixed assets & 5463 & 50.5 & Loan and other liabilities ${ }^{2)}$ & 1530 & 14.1 \\
\hline Dwellings & 3432 & 31.7 & Consumer loans & 198 & 1.8 \\
\hline Land underlying buildings & 1483 & 13.7 & Mortgage loans & 1037 & 9.6 \\
\hline Other buildings & 379 & 3.5 & Entrepreneurial loans & 286 & 2.6 \\
\hline Land underlying other buildings & 46 & 0.4 & Other liabilities & 9 & 0.1 \\
\hline Other fixed assets ${ }^{1)}$ & 124 & 1.1 & & & \\
\hline Financial assets ${ }^{2)}$ & 4424 & 40.9 & & & \\
\hline Currency and deposits & 1575 & 14.5 & & & \\
\hline Currency and transfer. deposits & 630 & 5.8 & & & \\
\hline Savings deposits and certificates & 945 & 8.7 & & & \\
\hline Mutual funds shares & 508 & 4.7 & & & \\
\hline Claims on insurance corporations ${ }^{3)}$ & 1227 & 11.3 & & & \\
\hline Short-term claims & 81 & 0.7 & & & \\
\hline Longer-term claims & 1146 & 10.6 & & & \\
\hline with life insurance companies & 718 & 6.6 & & & \\
\hline with health insurance schemes & 135 & 1.2 & & & \\
\hline with pension funds & 293 & 2.7 & Net wealth & 9296 & 85.9 \\
\hline Company pension commitments & 255 & 2.4 & & & \\
\hline Securities & 859 & 7.9 & $\begin{array}{l}\text { Net wealth ress } \\
\text { consumer durables companv }\end{array}$ & & \\
\hline Bonds, money market papers & 315 & 2.9 & $\begin{array}{l}\text { consumer aurables, company } \\
\text { pension commitments claims with }\end{array}$ & & \\
\hline Shares & 356 & 3.3 & pension commitments, clalms With & & \\
\hline Other equity & 188 & 1.7 & currency and transferable deposits, & & \\
\hline Consumer durables of households & 939 & 8.7 & consumer loans & 7242 & 66.9 \\
\hline Total & 10826 & 100.0 & Total & 10826 & 100.0 \\
\hline
\end{tabular}




\section{References}

Atkinson, Anthony B., Thomas Piketty (eds.) (2007): Top Income Over the Twentieth Century: A Contrast Between Continental European and English-Speaking Countries. Oxford University Press 2007.

Atkinson, Anthony B., Thomas Piketty (eds.) (2010): Top Incomes - A Global Perspective. Oxford University Press.

Bach, Stefan, Martin Beznoska, Viktor Steiner (2010): Aufkommens- und Verteilungswirkungen einer Grünen Vermögensabgabe. DIW Berlin: Politikberatung kompakt 59. http://www.diw.de/documents/publikationen/73/diw_01.c.366543.de/diwkompakt_2010-059.pdf

Boadway, Robin, Emma Chamberlain, Carl Emmerson (2010): Taxation of Wealth and Wealth Transfers. In: Dimensions of Tax Design. The Mirrlees Review. Institute for Fiscal Studies. Oxford University Press, 737-824. http://www.ifs.org.uk/mirrleesreview/dimensions/ch8.pdf

Eichengreen, Barry (1989): The Capital Levy in Theory and Practice. NBER Working Paper No. 3096. http://www.nber.org/papers/w3096

Frick, Joachim R., Markus M. Grabka, Jan Marcus (2007): Editing and Multiple Imputation of ItemNon-Response in the 2002 Wealth Module of the German Socio-Economic Panel (SOEP). DIW Berlin Data Documentation 18. http://www.diw.de/documents/publikationen/73/diw_01.c.56538.de/diw_datadoc 2007-018.pdf

Frick, Joachim R., Markus M. Grabka, Jan Marcus (2010): Editing und multiple Imputation der Vermögensinformation 2002 und 2007 im SOEP. DIW Berlin Data Documentation 51. http://www.diw.de/documents/publikationen/73/diw 01.c.359703.de/diw_datadoc_2010-051.pdf

Haisken-DeNew, John P., Joachim R. Frick (2005): DTC Desktop Companion to the German SocioEconomic Panel (SOEP). Version 8.0 - Dec 2005, Updated to Wave 21 (U). http://www.diw.de/documents/dokumentenarchiv/17/diw_01.c.38951.de/dtc.409713.pdf

IMF - International Monetary Fund (2010): A Fair and Substantial Contribution by the Financial Sector. Final Report for the G-20. June 2010. http://www.imf.org/external/np/g20/pdf/062710b.pdf

Klass, Oren S., Ofer Biham, Moshe Levy, Ofer Malcai, Sorin Solomon (2006): The Forbes 400 and the Pareto wealth distribution. Economics Letters 90, 290-295.

Kroh, Martin (2009): Short-Documentation of the Update of the SOEP-Weights, 1984-2008. DIW Berlin, Socio-Economic Panel Study. http://www.diw.de/documents/dokumentenarchiv/17/diw_01.c.342852.de/soep_weights_shortdocu.pdf

Kumar, Manmohan S., Jaejoon Woo (2010): Public Debt and Growth. IMF Working Paper No. 10/174. http://www.imf.org/external/pubs/ft/wp/2010/wp10174.pdf

mangager magazin (2007): Die 300 reichsten Deutschen. manager magazin spezial Oktober 2007. Datasets: http://www.meudalismus.dr-wo.de/html/stundenloehne2007.htm

OECD (2008): Growing Unequal? Income Distribution and Poverty in OECD Countries. Paris: OECD. http://www.oecd.org/document/53/0,3746,en_2649_33933 41460917_1_1_1_1,00.html

Reinhart, Carmen M., Kenneth S. Rogoff (2010): Growth in a Time of Debt. American Economic Review 100(2), 573-578.

Rudnick, Rebecca S., Richard K. Gordon (1996): Taxation of Wealth. In: Victor Thuronyi (Ed.):Tax Law Design and Drafting. Volume 1, Chapter 10. International Monetary Fund. http://www.imf.org/external/pubs/nft/1998/tlaw/eng/ch10.pdf

Wagner, Gert G., Joachim R. Frick, Jürgen Schupp (2007): The German Socio-Economic Panel Study (SOEP): Scope, Evolution and Enhancements. Schmollers Jahrbuch 127(1), 139-169.

Wiegand, Lutz (1992): Der Lastenausgleich in der Bundesrepublik Deutschland 1949 bis 1985. Frankfurt am Main: Lang. 